\title{
The Cyclic Helix and Cyclic Coil Forms of Polyoma Viral DNA
}

\author{
Roger Weil, and Jerome Vinograd
}

PNAS 1963;50;730-738

doi:10.1073/pnas.50.4.730

This information is current as of January 2007.

\begin{tabular}{|ll|}
\hline & This article has been cited by other articles: \\
& www.pnas.org\#therarticles \\
E-mail Alerts & $\begin{array}{l}\text { Receive free email alerts when new articles cite } \\
\text { this article - sign up in the box at the top right } \\
\text { corner of the article orclick here. }\end{array}$ \\
& $\begin{array}{l}\text { To reproduce this article in part (figures, tables) or } \\
\text { in entirety, see: } \\
\text { www.pnas.org/misc/rightperm.shtml } \\
\text { Rights \& Permissions }\end{array}$ \\
To order reprints, see: \\
www.pnas.org/misc/reprints.shtml
\end{tabular}

Notes: 
for its association with the chloroplast in vivo. Light microscope examination of the isolated chloroplast preparations indicates very low contamination with other cell particulates.

* Supported by grant E-1605 of the U.S. Public Health Service and institutional grant IN-4 of the American Cancer Society.

$\dagger$ Present address: Research Reactor Institute of Kyoto University, Osaka, Japan.

${ }^{1}$ Sze, L. C., J. Exptl. Zool., 122, 577 (1953); Stich, H. F., Exptl. Cell Res., 26, 136 (1962).

${ }^{2}$ Granick, S., in Encycl. Plant Physiol., 1, 507 (1955).

${ }^{3}$ Chevremont, M., Biochem. J., 85, 25 (1962).

${ }^{4}$ Clark, T. B., and F. G. Wallace, J. Protozool., 7, 115 (1960).

${ }^{5}$ Sager, R., these Proceedings, 48, 2018 (1962); Sager, R., and Z. Ramanis, these ProceedINGS, 50, 260 (1963).

${ }^{6}$ Ris, H., and W. Plaut, J. Cell Biol., 13, 383 (1962).

7 Chun, E. H. L., M. H. Vaughan, Jr., and A. Rich, J. Mol. Biol. 7, 130 (1963).

${ }^{8}$ Sager, R., and Granick, S., Ann. N. Y. Acad. sci., 56, 831 (1953); Ishida, M. R., and R. Sager, in preparation.

${ }^{9}$ We are indebted to Drs. S. I. Honda and S. Wildman who developed a medium for isolating higher plant chloroplasts and made it available to us. We modified their medium somewhat for use with Chlamydomonas.

${ }^{10}$ Marmur, J., J. Mol. Biol., 3, 208 (1961).

11 Meselson, M., F. W. Stahl, and J. Vinograd, these Proceedings, 43, 581 (1957).

12 Dische, Z., Mikrochemie, 2, 26 (1930); Ishida, M. R., Memo College Sci., Kyoto Univ. Ser B., 21, 55 (1954).

${ }_{18}$ Mejbaum, W., Z. physiol. Chem., 258, 117 (1939).

${ }^{14}$ Lowry, O. H., N. J. Rosebrough, A. L. Farr, and R. J. Randall, J. Biol. Chem. 73, 627 (1927).

${ }^{15}$ Wyatt, G. R., in The Nucleic Acids, ed. E. Chargaff and J. N. Davidson (New York: Academic Press, 1955), vol. 1, p. 243.

${ }^{16}$ Sager, R., and G. E. Palade, J. Biophys. Biochem. Cytol., 3, 463 (1957).

${ }^{17}$ Sueoka, N., these Proceedings, 46, 83 (1960).

${ }^{18}$ Sager, R., and Tsubo, Y., Arch. Mikrobiol., 42, 159 (1962); Sager, R., Genetics, 47, 982 (1962).

19 Park, R. B., and N. G. Pon, J. Mol. Biol., 6, 105 (1963).

${ }^{20}$ Calvin, M., Science, 135, 879 (1962).

${ }^{21}$ Ishida, M. R., and R. Sager, in preparation.

${ }^{22}$ Sager, R., unpublished.

\section{THE CYCLIC HELIX AND CYCLIC COIL FORMS OF POLYOMA VIRAL DNA}

\section{By Roger Weil aNd Jerome Vinograd}

GATES AND CRELLIN LABORATORIES OF CHEMISTRY* AND THE NORMAN W. CHURCH LABORATORY OF CHEMICAL BIOLOGY, CALIFORNIA INSTITUTE OF TECHNOLOGY

Communicated by R. Dulbecco, August 19, 1963

The DNA extracted from polyoma virus exhibits certain properties which have not been reported for other viral base-paired DNA's. ${ }^{1}$ The DNA renatures monomolecularly. The loss of helical configuration does not impair biological activity. Heating at $100^{\circ}$ for $10-20$ min followed by rapid cooling does not reduce the infective titer. Dulbecco has given evidence suggesting that a fraction of the polyoma DNA molecules are cyclic. ${ }^{2}$ This form would in part account for the above properties. 
The results reported in this communication give strong evidence for cyclic polyoma DNA molecules; they also define certain properties of the cyclic and open forms. Some of the evidence reported here is similar to that obtained in an independent investigation by Dulbecco and Vogt. ${ }^{3}$

Materials and Methods.-Isolation and purification of the virus and extraction of the DNA: The virus was isolated and purified by the procedure described by Winocour. ${ }^{4}$ The main visible band from the $\mathrm{CsCl}$ density gradient was collected, and the DNA extracted by a modified phenol procedure. ${ }^{1}$ The homogenization step was omitted. The $\mathrm{CsCl}, \mathrm{Harshaw}$ Chemical Company, Optical Grade, formed solutions which remained clear upon addition of alkaline buffers. Reagent grade inorganic chemicals and Merck's reagent grade formaldehyde were used.

Analytical ultracentrifugation: Sedimentation velocity analyses were performed in the Spinco analytical ultracentrifuge by band-centrifugation. ${ }^{5}$ Boundary-velocity experiments were precluded by the limited supply of the virus. Buoyant density experiments were performed at $44,770 \mathrm{rpm}$ at $25^{\circ} \mathrm{C}$ and analyzed by methods previously described. ${ }^{6}$

Preparation of the alkaline solutions: The alkaline $\mathrm{CsCl}$ solutions were prepared with the buffers described by Vinograd et al. ${ }^{7}$ The alkaline $\mathrm{NaCl}$ solutions were prepared by mixing 1 volume of $4 \mathrm{M} \mathrm{NaCl}$ with 3 volumes of $0.11 \mathrm{M} \mathrm{KOH.} .^{\mathrm{7a}}$ The pH measured with a small generalpurpose Beckman glass electrode was 12.2 \pm 0.1 . DNA samples were made alkaline in the sample hole by addition of 1 volume of $1.1 \mathrm{M} \mathrm{KOH}^{7 \mathrm{a}}$ to 9 volumes of DNA solution, and mixed by drawing the solutions back into the Kel-F tubing several times. The final $\mathrm{pH}$ was $12.5 \pm 0.2$. Preincubation for longer periods was performed in 0.032-in. I.D. Kel-F tubing sealed at both ends with 4-mm plugs of silicone grease.

Denaturation and renaturation: These experiments were performed as previously described. ${ }^{1}$ Formaldehyde denaturations ${ }^{8}$ were performed with $25 \mu \mathrm{l}$ samples in $11 \% \mathrm{CH}_{2} \mathrm{O}, \mathrm{pH} 8.3$, ionic strength 0.01 , in sealed glass melting-point tubes at $70-75^{\circ} \mathrm{C} 2-3 \mathrm{~min}$ followed by chilling at $0^{\circ} \mathrm{C}$.

Sonication: The DNA solutions in thin 1-ml nitrocellulose test tubes were sonicated in a 9,000 cps Raytheon Sonicator Model no. S102A at the indicated power level.

Calculations: The molecular weight of anhydrous NaDNA was calculated from the standard deviation of the band. ${ }^{6}$ The additional cesium ions and preferential hydration ${ }^{7}$ introduced at high $\mathrm{pH}$ were included in the calculations. Buoyant densities were measured with $M$. lysodeikticus DNA, $\rho_{0}^{0}=1.732 \mathrm{gm} \mathrm{cm}^{-3}$, as a reference, a value based on $\rho_{0}^{0}=1.710 \mathrm{gm} \mathrm{cm}^{-3}$ for DNA from E. coli. ${ }^{9}$ This value disagrees with a recent redetermination by $+0.006 \mathrm{gm} \mathrm{cm}^{-3} .{ }^{7}$

Results.- Sedimentation analysis of DNA extracted from the virus: Band-centrifugation analyses of the DNA from six different virus batches all showed three components which we refer to as I, II, and III, in order of decreasing sedimentation coefficients. The values, $\mathrm{s}_{20, w}^{\circ}$, in $1 M \mathrm{NaCl}, 0.01 M \mathrm{Na}_{2} \mathrm{HPO}_{4}, \mathrm{pH} 8.0$ were $20.3 \mathrm{~S} \pm 0.4$ S.D., $15.8 \mathrm{~S} \pm 0.4$ S.D., and $14.4 \mathrm{~S}^{10}$ (Fig. $1 A$ ). The component composition was determined in $3.5 \mathrm{M} \mathrm{CsCl}$ (Fig. $1 B$ ). In this solvent the band profiles are more symmetrical than in $1 M \mathrm{NaCl}$ or $1 M \mathrm{CsCl}$. In all preparations

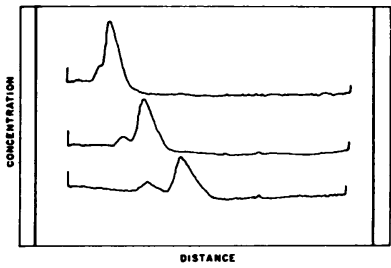

(A)

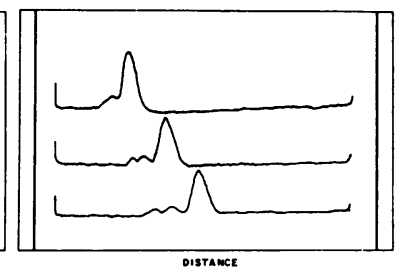

(B)

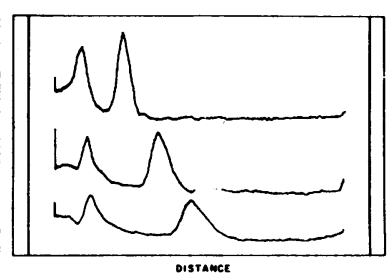

(C)

FIg. 1.-Band sedimentation velocity analyses of polyoma DNA in $(A)$ neutral $\mathrm{NaCl},(B)$ neutral CsCl, $(C)$ alkaline NaCl. $(A)$ Lamella: $15 \mu \mathrm{l}, 24 \mu \mathrm{g} / \mathrm{ml}$ DNA; bulk solution: $1 M$ NaCl, 0.01 $M \mathrm{Na}_{2} \mathrm{HPO}_{4}, \mathrm{pH} 8.0$. Densitometer records are from photographs taken at 16-min intervals. $35,600 \mathrm{rpm}, 20^{\circ}$. (B) Lamella: $20 \mu \mathrm{l}, 60 \mu \mathrm{g} / \mathrm{ml}$ DNA; bulk solution: $\mathrm{CsCl}, \rho=1.36,0.01 M$ Tris, pH 8.1. 16-min intervals, 35,600 rpm, 20 . (C) Lamella: $25 \mu \mathrm{l}, 24 \mu \mathrm{g} / \mathrm{ml} \mathrm{DNA,} \mathrm{pH}=12.75$ bulk solution: $1.0 \mathrm{M} \mathrm{NaCl}, 0.10 \mathrm{M} \mathrm{KOH}, \mathrm{pH} 12.2$, 8-min intervals. $35,600 \mathrm{rpm}$. 
I comprised 80-90 per cent of the DNA. Component II varied between 1 and 20 per cent and III between 1 and 10 per cent. DNA released from the virus in the sample hole, $\mathrm{pH} 11.2$ or $\mathrm{pH} 12.3$, gave patterns indistinguishable from those obtained with the phenol extract. The sedimentation pattern at neutral $\mathrm{pH}$ did not change upon storage at $4^{\circ}$ for periods up to 20 weeks, or upon freezing and thawing. The DNA formed a single band at equilibrium in $\mathrm{CsCl}$ with a buoyant density of $1.709 \mathrm{gm} \mathrm{cm}^{-3}$. All preparations formed bands which were skewed on the light side. It is shown later that this skewness is due to III.

The renaturation behavior of polyoma DNA suggested that the strands did not physically separate when heated under conditions in which strand separation normally occurs. To examine this problem we employed the procedure described by Freifelder and Davison. ${ }^{8}$ Solutions of polyoma DNA were denatured in $\mathrm{CH}_{2} \mathrm{O}$ and examined in sedimentation velocity experiments in 11 per cent $\mathrm{CH}_{2} \mathrm{O}$, $1 M \mathrm{NaCl}$. The DNA now sedimented in two components (80 per cent fast) with a ratio of sedimentation coefficients of 2.2. This result was not compatible with the hypothesis that the fast material represented singly cross-linked double strands, and the slow material single strands ${ }^{8}$ because a ratio of $\sqrt{2}$ is to be expected. Strand separation was also examined at high $\mathrm{pH}, 12.2 \pm 0.1$, in $1 M \mathrm{NaCl}$. In this solvent, complete strand separation is to be expected. ${ }^{7}$ All fresh polyoma DNA preparations, including those stored at $-70^{\circ} \mathrm{C}$, sedimented in two wellresolved components ${ }^{11}$ (about three-fourths fast) with sedimentation coefficients, $\stackrel{\circ}{\mathrm{s}_{20, w}}$ of $53.1 \mathrm{~S} \pm 0.3 \mathrm{~S} . \mathrm{D}$. and $14.6 \mathrm{~S} \pm 0.5 \mathrm{~S} . \mathrm{D}$. (Fig. $1 C$ ). We will refer to the alkali components as the $53 \mathrm{~S}$ and $15 \mathrm{~S}$ DNA's and will show below that these are double-stranded cyclic coils and single-stranded random coils, respectively. That both of these components can derive from I was shown in experiments in which the DNA was so dilute that II and III could not be detected at $\mathrm{pH} 8$; in alkali, however, both the $53 \mathrm{~S}$ and $15 \mathrm{~S}$ components were observed.

The sedimentation velocity of the $15 \mathrm{~S}$ DNA was compared with the sedimentation velocity of $\phi \mathrm{X}-174 \mathrm{DNA}(16.0 \mathrm{~S})$ in the same solvent, and its molecular weight calculated with the relation for random coils, $\mathrm{S}_{1} / \mathrm{S}_{2}=\left(\mathrm{M}_{1} / \mathrm{M}_{2}\right)^{0.5}$. With $\mathrm{M}=1.7 \times 10^{6}$ for $\phi \mathrm{X}-174 \mathrm{DNA}^{12}$ we obtain $\mathrm{M}=1.4 \times 10^{6}$ for the $15 \mathrm{~S} \mathrm{com-}$ ponent. The same value is obtained if we use single-stranded T-7 DNA as a reference in this calculation, $\mathrm{s}_{20, w}=39 \mathrm{~S}, \mathrm{M}=9.5 \times 10^{6} .{ }^{13}$

Fresh polyoma DNA forms two well-separated bands in buoyant density experiments in alkaline $\mathrm{CsCl} \mathrm{pH} \mathrm{12.3.} \mathrm{In} \mathrm{band-buoyancy} \mathrm{experiments} \mathrm{(band-centrifuga-}$ tion performed with buoyant bulk solutions ${ }^{5}$ ) (Fig. 2), the $53 \mathrm{~S}$ DNA forms a band at a higher density than the 15 S DNA. The buoyant densities are 1.784 and 1.766 $\mathrm{gm} \mathrm{cm}^{-3}$, referred to 1.710 for $E$. coli DNA. The molecular weight calculated from several band profiles for the $53 \mathrm{~S}$ DNA was $2.4 \pm 0.3 \times 10^{6}$. The band formed by the 15 S DNA was skewed on the light side because of slowly sedimenting DNA and a small amount of III.

With a ratio of molecular weights $M_{53} s / M_{15 s} \approx 2$, as indicated in the arguments in the above two paragraphs, we expect for random coils a ratio of sedimentation coefficients of 1.4. The high velocity, $53 \mathrm{~S}$, in alkali of the double-stranded DNA has thus to be attributed to a drop in the frictional coefficient by a factor of 2.5 relative to a random coil containing two strands (Fig. 3). We therefore propose that the double-stranded cyclic helix denatures to form a double-stranded cyclic 
coil in which the turns originally present in the helix are conserved. The topological constraint imposes a compact structure on this molecule (Fig. 3) and gives rise to an unusually high sedimentation coefficient and buoyant density.

Several physical and chemical agents can convert the cyclic helix, the linear helix and the doublestranded cyclic coil to single strands, as well as the cyclic helix to the double-stranded cyclic coil and to the linear helix.

(1) Exposure to high $p H$ : After the initial rapid conversion of about one fourth of component $I$ into single strands, a further conversion into single-stranded $15 \mathrm{~S}$ DNA occurs at a slow rate. For example, after $72 \mathrm{hr}$ incubation at $\mathrm{pH} 12.1 \mathrm{in}$ $0.01 M \mathrm{NaCl}$, the amount of $53 \mathrm{~S}$ DNA decreased to about one third with a concomitant increase in $\mathbf{1 5}$
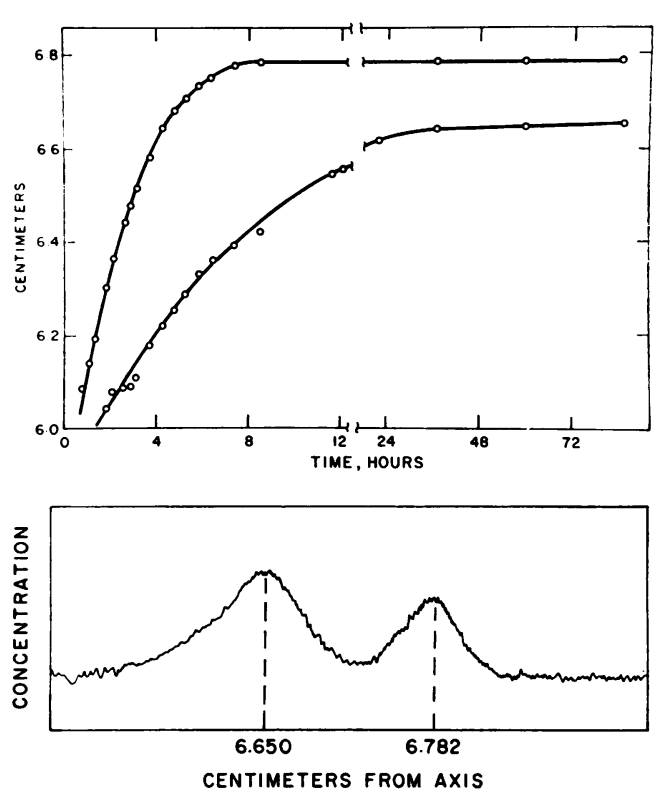

FIg. 2.-Band-buoyancy analysis of polyoma DNA in alkaline CsCl. Lamella: $20 \mu \mathrm{l}, 24 \mu \mathrm{g} / \mathrm{ml}$ DNA, pH 12.75. Bulk solution: $\mathrm{CsCl}, \rho=1.76$, $0.04 M \mathrm{~K}_{3} \mathrm{PO}_{4}, \mathrm{pH}=12.35$. 44,770 rpm. Upper: position of $15 \mathrm{~S}$ and $53 \mathrm{~S}$ components at various times. Lower: densitometer records of bands at $72 \mathrm{hr}, 25^{\circ}$. S DNA. Unlike the usual $15 \mathrm{~S}$

DNA, this material contained two velocity components, a small fraction, presumably cyclic single strands, sedimenting about 10 per cent faster than the main component. ${ }^{11}$ The patterns were similar to those observed in experiments with $\phi \mathrm{X}-174$ DNA, which contained both linear and circular molecules. ${ }^{14}$

(2) Exposure to high $\mathrm{CsCl}$ concentrations: The sedimentation velocity patterns of polyoma DNA in dilute $\mathrm{CsCl}$ solutions are skewed because of the effects of concentration-dependent sedimentation. At a density of $1.35 \mathrm{gm} \mathrm{cm}^{-3}$ the bands become symmetrical, presumably because of a reduction in the equivalent hydrodynamic volume.

At still higher concentrations of $\mathrm{CsCl}, \rho=1.5$ and $\rho=1.6$, the relative amounts of the components changed in two of the three preparations studied. Component I became smaller and II larger. That this conversion is not rapidly reversible was shown in experiments in which polyoma $\mathrm{DNA}$ was incubated at $23^{\circ} \mathrm{C}$ in $\mathrm{CsCl}$, $\rho=1.72,0.006 M \mathrm{Na}$ citrate pH 7.0 for 1,24 , and $44 \mathrm{hr}$, and subsequently analyzed, after dilution, in $\mathrm{CsCl}, \rho=1.35 \mathrm{gm} \mathrm{cm}^{-3}$. Analyses in neutral $\mathrm{CsCl}$ showed that irreversible conversion of $I$ in all three DNA preparations had occurred to the extent of 50,75 , and 90 per cent, respectively. In one of the preparations of DNA it was confirmed that the conversion noted after $44 \mathrm{hr}$ by analysis in neutral $\mathrm{CsCl}$ represented a ring cleavage. This was shown by a change in the relative amounts of fast and slow forms in alkaline $\mathrm{CsCl}, \rho=1.36,0.04 M \mathrm{~K}_{3} \mathrm{PO}_{4}, \mathrm{pH}=12.1$. The ratio of amounts changed from 0.6 to 0.1 . The corrected sedimentation coefficients, $\mathbf{s}_{20, w}^{\mathbf{0}} \eta_{\text {rel }}$, for the double-stranded cyclic coils and the single-stranded coils 
were $37 \mathrm{~S}$ and $11.6 \mathrm{~S}$. These results indicate that preparative equilibrium sedimentation in $\mathrm{CsCl}$ at room temperature can lead to a substantial loss of the cyclic helical form.

(3) Exposure to high $\mathrm{CsCl}$ concentration at high $\mathrm{pH}$ : A series of buoyant density experiments were performed to examine the effects of $\mathrm{pH}$. At $\mathrm{pH} 11$,

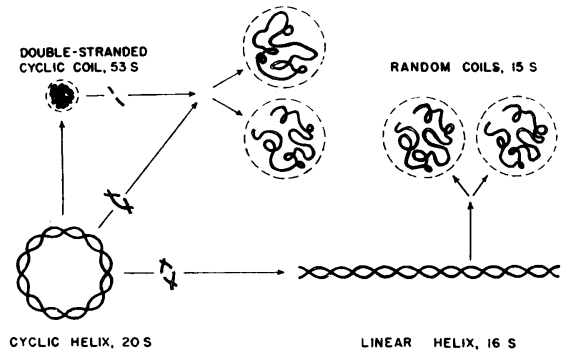

FIg. 3.-Diagrammatic representation of the two forms of polyoma DNA. The double-stranded cyclic helix denatures to form a double-stranded cyclic coil. The linear helix denatures to form two single-stranded random coils. The dashed circles indicate the relative equivalent hydrodynamic diameters. Possible links between chains or special bonds connecting chain ends are not considered. The sedimentation coefficients of the helices and coils were measured in neutral and alkaline $\mathrm{NaCl}$ solutions, respectively.

as at $\mathrm{pH} 8.1$, the buoyant density was $1.709 \mathrm{gm}^{-3}$, and the band was skewed at the light side. At $\mathrm{pH} 11.8$ a substantial fraction of the DNA titrated to form a band at $1.766 \mathrm{gm} \mathrm{cm}^{-3}$ that was skewed at the light side while the remainder, the intact cyclic helical DNA, formed a symmetrical band at $1.714 \mathrm{gm}^{-3} \mathrm{~cm}^{-11}$ At $\mathrm{pH} 12.2$ the latter material denatured and titrated to form a band of doublestranded cyclic coils at $1.784 \mathrm{gm} \mathrm{cm}^{-3}$. The results show that the cyclic helix is more stable than the linear helix to alkali denaturation. Both at $\mathrm{pH} 11.8$ and 12.2 the relative amounts of the double-stranded cyclic DNA were smaller than the relative amount of $53 \mathrm{~S}$ DNA initially present in the preparations. A portion of the double-stranded cyclic DNA was therefore converted to single strands.

(4) Sonication: Sonication at 75 per cent full power for 1.5 and 5 min gave the same results. The relative amount and the sedimentation coefficient of I were essentially unchanged in neutral $1 \mathrm{M} \mathrm{NaCl}$ (Fig. 4). Components II and III formed a relatively broad band with decreased sedimentation coefficient, $12.2 \mathrm{~S}$. At full power, sonication for 2 and 4 min resulted in the conversion of 50 and 80 per cent, respectively, of I into a slower material, $8.3 \mathrm{~S}$. In previous studies with native DNA's, the resistance to shearing increases with decreasing sedimentation coefficient. ${ }^{15}$ We have here the reverse effect, presumably because the extended length of the cyclic form is less than that of the linear form.

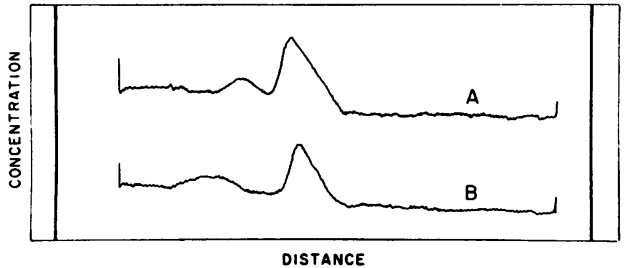

Frg. 4.-Effect of sonication of polyoma DNA. $(A)$ untreated; $(B)$ sonicated $1.5 \mathrm{~min}$. Lamella: $15 \mu \mathrm{l}, 25 \mu \mathrm{g} / \mathrm{ml}$ DNA. Bulk solution: $1.0 \mathrm{M}$ $\mathrm{NaCl}, 0.01 M \mathrm{NaHPO}_{4}$, pH 8.0. Photographed $64 \mathrm{~min}$ after reaching full speed. $35,600 \mathrm{rpm}$, $20^{\circ}$.
(5) Effects of heating at $100^{\circ} \mathrm{C}$ : Component III is selectively melted out and becomes polydisperse in neutral sedimentation velocity experiments performed after heating solutions of polyoma DNA in $0.4 M$ $\mathrm{NaCl} 1-2 \mathrm{~min}$ at $100^{\circ}$ followed by rapid cooling. The skewness disappears from the main band in buoyant density experiments at neutral pH. Component III forms a band of denatured DNA with a buoyant 
density $1.721 \mathrm{gm} \mathrm{cm}^{-3}, 0.003 \mathrm{gm} \mathrm{cm}^{-3}$ less than the buoyant density of denatured polyoma DNA. In these experiments the relative amounts and the sedimentation velocities of I and II were unchanged. Longer heating leads to gradual conversion of I into a 16 S DNA.

When fresh polyoma DNA at a concentration of $1-2 \mu \mathrm{g} / \mathrm{ml}$ was heated at $100^{\circ}$ 1-2 min in buffers of low ionic strength followed by rapid cooling, I renatured nearly completely, while an amount corresponding to II and III remained denatured as judged by buoyant density. This result indicates that intact cyclic coils renature readily. Upon further heating, increasing amounts of denatured DNA were formed. Heated materials analyzed in alkali contained decreasing amounts of $53 \mathrm{~S}$ DNA and increasing amounts of $15 \mathrm{~S}$ DNA. Depurination which occurs on heating and leads to chain scission in alkali ${ }^{16-18}$ is in part responsible for the conversion of doublestranded cyclic coils to random coils.

Electron microscopy: The striking and important result is that cyclic molecules are observed (see Appendix).

Discussion.-The major fraction of polyoma DNA denatures in alkali and remains double-stranded. A smaller fraction denatures in alkali to form single strands with about half the molecular weight of the double-stranded form. Comparison of the sedimentation coefficients in alkali of these two denatured DNA's with each other and with the sedimentation coefficients in alkali of other DNA single strands of known molecular weight leads to the conclusion that the denatured double-stranded polyoma DNA has an abnormally low frictional coefficient. A simple model for the native DNA which can account for the properties mentioned is a cyclic helix with separately continuous strands (Fig. 3).

The requirement that the approximately 500 turns originally present in the helical structure be conserved as long as the strands remain continuous leads necessarily to a configuration for the denatured molecule which is more compact than the random-coil configuration. Any spatial rearrangement of the phosphodiester chains upon denaturation gives rise to supercoiling. This new type of DNA coil, which we refer to as the double-stranded cyclic coil, has an abnormally high sedimentation coefficient and a higher buoyant density in alkaline cesium chloride than the random coil.

The introduction of one discontinuity in one of the strands in the native or denatured double-stranded molecule results in the formation in alkali of single strands, one linear and one cyclic. The finding that the molecular weight is always first reduced by a factor of 2 upon degradation shows that the strands in polyoma DNA are separately continuous. None of the foregoing excludes the additional presence of a cross-link labile in alkali. Further evidence for a cyclic structure for component I is the relatively high resistance to shearing by sonication, and the presence in the electron micrographs of about 90 per cent cyclic molecules.

We now examine the evidence that II is an open or linear form of the cyclic helix I. The buoyant density of II is essentially the same as I. Upon thermal denaturation of II, a buoyant density shift characteristic for double-stranded DNA is observed. The alkaline buoyant density shift is also normal for a linear helix. We conclude therefore that II is a linear helix. $\mathrm{I}$ is converted into $16 \mathrm{~S}$ helical DNA by the action of concentrated $\mathrm{CsCl}$ or heating at $100^{\circ}$ in $0.4 \mathrm{M} \mathrm{NaCl}$. 
The sedimentation coefficient of II is slightly lower than I, which is reasonable for the proposed relation between I and II. That II has the same molecular weight as $I$ is indicated by the formation from II in alkali of $15 \mathrm{~S}$ single strands of one half the molecular weight of I. These arguments all suggest that II is an open or linear form of the cyclic helix I. Consistent with the above conclusion is the greater sensitivity of II to sonication, and the appearance in the electron micrographs of linear and cyclic molecules with the same mean length.

The origin of III, which was present in small amounts in all preparations, is not known. Its homogeneity with respect to sedimentation velocity and buoyant behavior rules out an adventitious contamination by host cell DNA. Component III was not found by Dulbecco and Vogt ${ }^{3}$ in radioactively labeled polyoma DNA preparations, or by Crawford (cf. ref. 10) with boundary-sedimentation velocity experiments. Either the methods used by these investigators were not sufficiently sensitive or III represents a well-defined host cell DNA molecule which was synthesized prior to viral infection and thus remained unlabeled.

The thermal stability ${ }^{1}$ of the infective titer of polyoma DNA upon heating at $100^{\circ}$ can now be interpreted. The initial threefold increase in infective titer is the

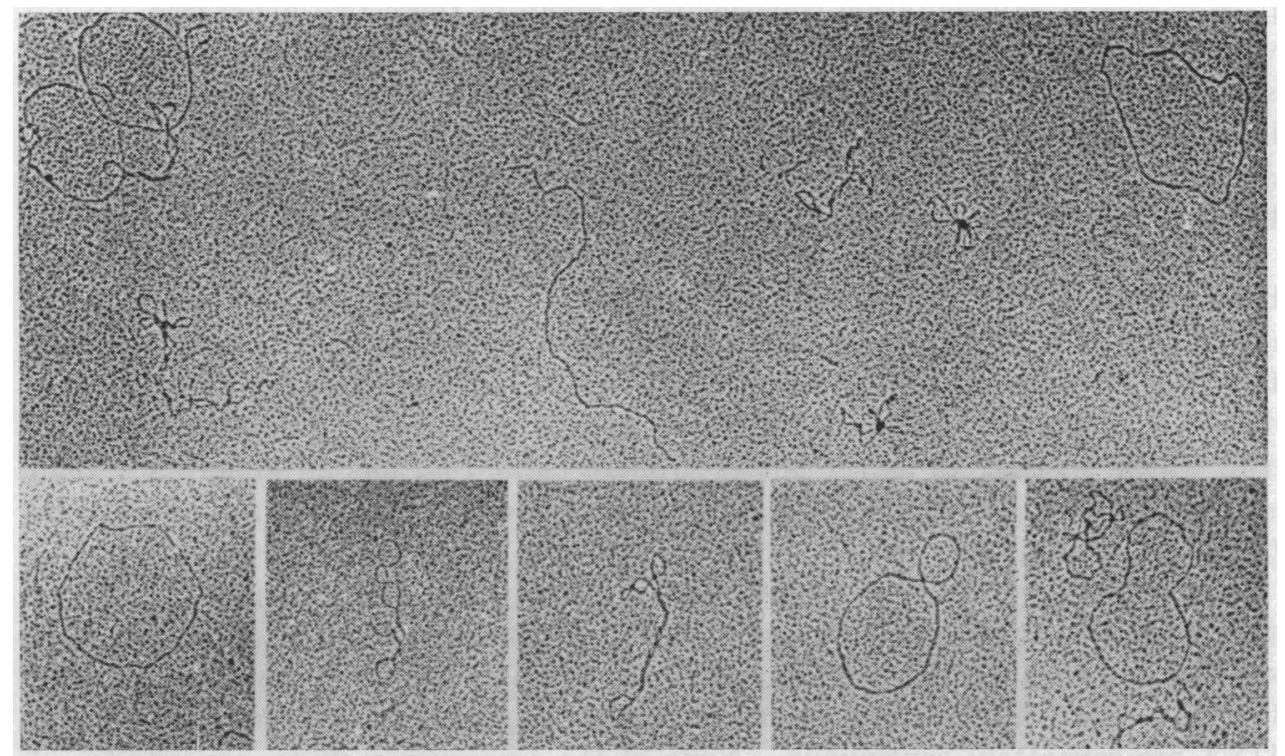

FIG. 5.-Electron micrographs of polyoma DNA, $\times 44,000$. Upper: a field showing linear and cyclic forms. Lower: selected cyclic forms.

result of a more efficient attachment of the DNA to the mouse cells in the assay for infectivity. ${ }^{1}$ The essentially unchanged titer during the next $10-20 \mathrm{~min}$ is attributed to a steady state between a thermal activation and an inactivation process. In the activation process the cyclic double-stranded molecule is opened to produce a molecule of higher infectivity. If a cleavage occurs at a phosphodiester bond, a pair of linear and cyclic single strands is formed. These separate unless held together by a cross link which we have not ruled out. If a cleavage at the site of a 
linker connecting four chain ends occurs, either single- or double-stranded linear molecules are formed. When all cyclic double-stranded molecules have been opened, the reservoir of potential infectivity is exhausted. Further heating leads to an exponential decrease in the infective titer.

The opening of the ring at high $\mathrm{pH}$ or as a result of heating may proceed by well-known reactions such as hydrolysis or depurination followed by hydrolysis; and these may occur at any site along the chains. The slow cleavage of the ring in concentrated neutral $\mathrm{CsCl}$ solutions is a surprising result which suggests that polyoma DNA contains a labile site in the chain not present in other biologically active DNA's which have been routinely studied in and recovered from equilibrium density gradient experiments in concentrated $\mathrm{CsCl}$ solutions.

\section{APPENDIX BY WALTHER STOECKENIUS}

\section{THE ROCKEFELLER INSTITUTE}

Three different configurations of polyoma viral DNA are visible in the electron micrographs (Fig. 5): coiled molecules without visible free ends, fully extended cyclic molecules, and linear molecules. If a coiled form contained not more than two twists, its length could be accurately measured. In a given typical area, 83 coiled, 8 extended, and 9 linear molecules were observed. The mean lengths of 66 cyclic and 68 linear molecules were $1.58 \mu \pm 0.16$ S.D. and $1.53 \mu \pm 0.16$ S.D., respectively. These lengths correspond to a molecular weight of $3.0 \times 10^{6}$, if we assume that the mass per unit length of DNA molecules in the protein film is the same as in the B-form in fibers of NaDNA. ${ }^{19-21}$

Electron microscopy thus confirms that polyoma DNA molecules exist in linear and cyclic forms of equal molecular weight. The proportion of I and II by electron microscopy corresponds to that found by sedimentation analysis, as described below.

A striking feature of the electron micrographs is the high proportion of tightly coiled molecules. In otherwise identical preparations of T-7 DNA, linear molecules and a very few tightly coiled molecules were found. The latter form is probably due mainly to intramolecular cross-linking by protein. ${ }^{21}$ The absence of free ends in the tightly coiled polyoma DNA molecules indicates that they are cyclic; the high proportion of such forms suggests that cyclic molecules are more readily crosslinked by protein. Component III could not be identified in the electron micrographs.

A sample containing $2 \mu \mathrm{g} / \mathrm{ml}$ polyoma DNA in $0.006 M \mathrm{KCl}, 0.01 M$ Tris, pH 7.5 was shipped in dry ice, thawed, and frozen three times during these studies, and the remainder returned in dry ice. Re-examination (by R. W. and J. V.) at neutral pH in $1.0 M \mathrm{NaCl}$ and $3.5 M \mathrm{CsCl}$ showed an unchanged composition, $85 \%$ I and about equal amounts of II and III. In alkaline $\mathrm{NaCl}$ only slow polydisperse strands were found.

Grids were prepared by the method of Kleinschmidt and Zahn, ${ }^{22}$ except that diisopropylphosphoryl trypsin (Worthington Biochemical Corp., no. TRL-DIP104) was used instead of cytochrome $\mathrm{C}$ and the solution was delivered to the surface via a glass rod. ${ }^{23}$ One ml of solution $\left(0.24 \mu \mathrm{g}\right.$ DNA, $100 \mu \mathrm{g}$ DIP-trypsin in $1.0 \mathrm{M} \mathrm{NH}_{4}$ acetate, $\mathrm{pH}$ 8.0) was delivered onto $0.015 M$ $\mathrm{NH}_{4}$ acetate, $\mathrm{pH}$ 8.0. The resulting surface film was compressed to $1.0 \mathrm{dyne} / \mathrm{cm}$ at about 450 $\mathrm{cm}^{2}$. Randomly selected portions of the surface film were picked up on platinum grids and shadowed with uranium at an angle of $7^{\circ}$ while the specimen was rotating.

Summary.-The results obtained in this study show that polyoma viral DNA contains linear and cyclic helical molecules. The double-stranded cyclic helix de- 
natures in alkaline solutions to form a double-stranded cyclic coil, a new type of coiled molecule in which all of the turns originally present in the helix are conserved.

It is a pleasure to thank R. W. Watson for expert technical assistance, R. D. Bruner for helpful discussions during the preparation of the manuscript, R. Dulbecco for providing the polyoma virus, R. L. Sinsheimer and P. F. Davison for gifts of materials, and R. Dulbecco and M. Vogt for a copy of their unpublished manuscript. This work was supported in part by grants $\mathrm{HE}$ 03394 and GM 08812 from the U.S. Public Health Service.

* Contribution 3018 of Gates and Crellin Laboratories of Chemistry.

${ }^{1}$ Weil, R., these Proceedings, 49, 480 (1963).

${ }^{2}$ Dulbecco, R., in Monograph of the 17th Annual Symposium on Fundamental Cancer Research, M. D. Anderson Hospital, Houston, Texas, Feb. 20, 1963 (Baltimore: Williams and Wilkins), in press.

${ }^{3}$ Dulbecco, R., and M. Vogt, these Procendings, 50, 236 (1963).

${ }^{4}$ Winocour, E., Virology, 19, 158 (1963).

${ }^{5}$ Vinograd, J., R. Bruner, R. Kent, and J. Weigle, these Proceedings, 49, 902 (1963).

${ }^{6}$ Vinograd, J., and J. Hearst, Prog. in Chem. Org. Nat. Prods., 20, 372 (1962).

7 Vinograd, J., J. Morris, N. Davidson, and W. F. Dove, Jr., these Proceedings, 49, 12 (1963).

7a These solutions were not free of carbon dioxide.

${ }^{8}$ Freifelder, D., and P. F. Davison, Biophys. J., 3, 49 (1963).

${ }^{9}$ Schildkraut, C. L., J. Marmur, and P. Doty, J. Mol. Biol., 4, 430 (1962).

${ }^{10}$ This value was obtained from the relative values of sedimentation coefficients of I and III in $\mathrm{CsCl}, \rho=1.35$, and the value for $\mathrm{s}_{: 0, w}^{\circ}$ for $\mathrm{I}$ in $1.0 \mathrm{M} \mathrm{NaCl}$. L. V. Crawford in Virology, 19, 279 (1963), obtained $21 \mathrm{~S}$ and $14 \mathrm{~S}$ for two components in polyoma DNA.

${ }^{11}$ Similar results were obtained independently by Dulbecco and Vogt. ${ }^{3}$

12 Sinsheimer, R. L., J. Mol. Biol., 1, 43 (1959).

${ }^{13}$ Davison, P. F., and D. Freifelder, J. Mol. Biol., 5, 643 (1962).

${ }^{14}$ Fiers, W., and R. L. Sinsheimer, J. Mol. Biol., 5, 424 (1962).

${ }^{15}$ Rosenkranz, H. S., and A. Bendich, J. Am. Chem. Soc., 82, 3198 (1960).

${ }^{16}$ Greer, S., and S. Zamenhof, J. Mol. Biol., 4, 123 (1962).

${ }^{17}$ Tamm, C., H. S. Shapiro, R. Lipshitz, and E. Chargaff, J. Biol. Chem. 203, 673 (1953).

${ }^{18}$ Fiers, W., and R. L. Sinsheimer, J. Mol. Biol., 5, 420 (1962).

${ }^{19}$ Wilkins, M. H. F., G. Zubay, and H. R. Wilson, J. Mol. Biol. 1, 179 (1959).

${ }^{20}$ Zubay, G., and M. H. F. Wilkins, J. Mol. Biol., 4, 444 (1962).

${ }^{21}$ Stoeckenius, W., J. Biophys. Biochem. Cytol., 11, 297 (1961).

${ }^{22}$ Kleinschmidt, A. K., and R. K. Zahn, Z. Naturforsch., 14b, 770 (1959).

${ }^{23}$ Trurnit, H. J., J. Colloid Sci., 15, 1 (1960).

\title{
REPLICATION OF NUCLEIC ACIDS
}

\author{
By Herbert Jehle, Michael L. Ingerman, Raymond M. Shirven, \\ William C. Parke, and Abigail A. Salyers
}

DEPARTMENT OF PHYSICS, THE GEORGE WASHINGTON UNIVERSITY

Communicated by Linus Pauling, July 15, 1963

Several model schemes have been proposed to explain the replication of nucleic acids, in particular the sequence selection of filial nucleotides when a doublestranded nucleic acid undergoes semiconservative replication. (These schemes usually are concerned with a Watson-Crick type DNA, although similar schemes might involve a filial RNA strand.) Two difficulties involved in previously proposed schemes are the unexplained accuracy of replication of nucleotide sequences 